\title{
Recovery measures for the tourism sector in Latin America and the Caribbean present an opportunity to promote sustainability and resilience
}

\section{Summary}

Tourism in the region has come to a temporary standstill, beginning in April 2020, as a result of the coronavirus disease (COVID-19) pandemic. This paralysis has not only hit Caribbean economies and employment hard, but also many local communities in Latin America. In this brief, the contribution of tourism to exports, gross domestic product (GDP) and employment is reviewed, together with the recent downturn in this activity in the region. An impact scenario shows that the slump in tourism may cause total GDP growth in the Caribbean and Latin America to fall by 8 percentage points and 1 percentage point, respectively, while total employment could potentially decline by 9 percentage points in the Caribbean and 2 percentage point in Latin America. As countries have taken measures to mitigate the impact of the crisis on tourism, recommendations are provided to step up the sector's preparation for the economic recovery, while enhancing diversification as well as environmental and social sustainability.

\section{A. The key role of tourism in exports, GDP and employment}

The COVID-19 pandemic has not only caused a humanitarian disaster but has also paralysed key sectors, such as tourism. This sector was one of the first and hardest hit parts of the economy. According to the World Tourism Organization (UNWTO, 2020), international tourist arrivals may fall by between $58 \%$ and $78 \%$ in 2020 . This sector is not only one of the main contributors to exports, the economy and employment in the Caribbean, but also in many cities and local communities in Latin America.

Tourism is a key generator of foreign exchange, income and employment across the region. In 2019, it accounted for $42 \%$ and $10 \%$ of total exports (goods and services) in the Caribbean and in Latin America, respectively. Its share exceeded $50 \%$ in some countries of the Caribbean (see figure 1.A). The tourism economy, which includes both tourism and all sectors that depend on it, represented 26\% of total GDP in the Caribbean and $10 \%$ in Latin America. As the tourism economy is highly labour intensive, it accounted for $35 \%$ of employment in the Caribbean and 10\% in Latin America (see figure 1.B). In the Caribbean, the tourism sector depends almost entirely on foreign visitors. In contrast, domestic visitors account for almost three quarters of the total in Mexico, while in some South American countries (such as Argentina, Brazil, Chile and Peru) this share is above 50\%.

\section{Summary}

A. The key role of tourism in exports, GDP and employment

B. The dramatic fall in tourism

C. Substantial impact on exports, GDP and employment

$D$. Different measures can mitigate the impact of the crisis and accelerate recovery

Bibliography
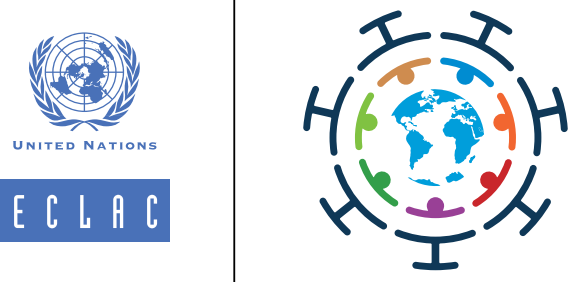
Figure 1

Latin America and the Caribbean (33 countries): share of tourism in total exports, GDP and employment, 2019

(Percentages)

\section{A. Share of tourism in exports of goods and services}

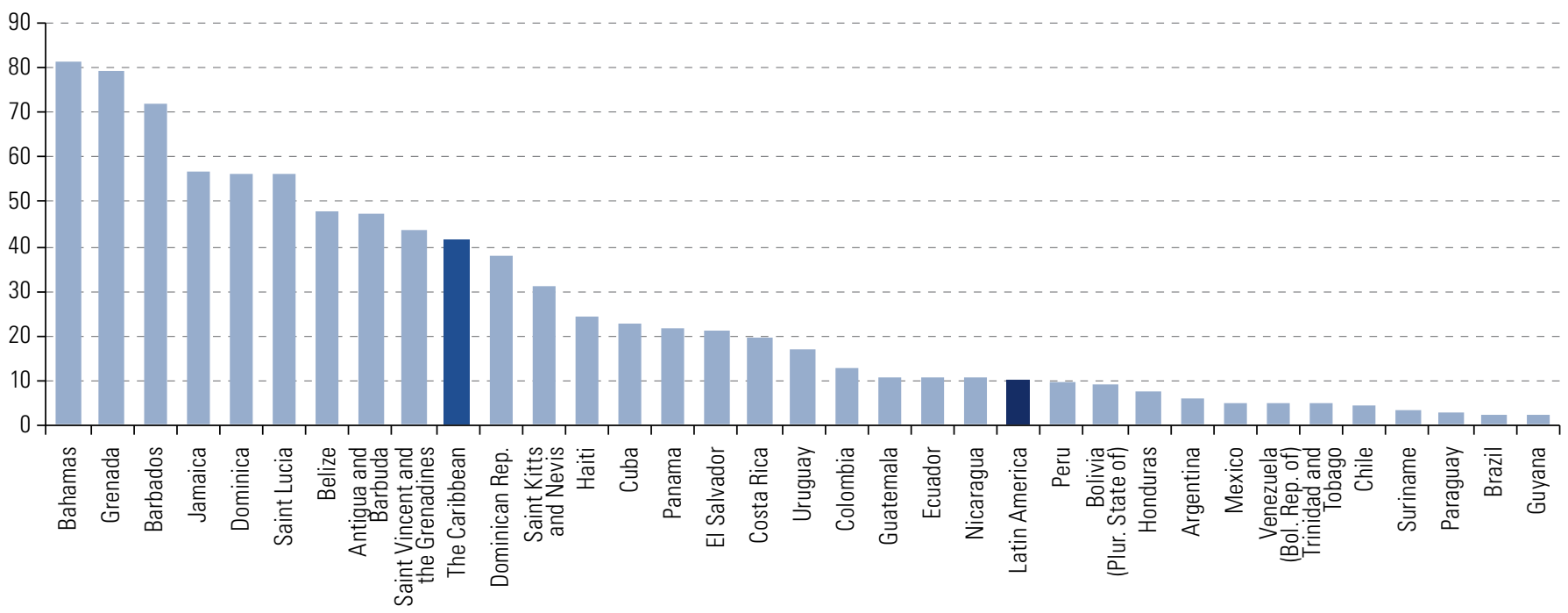

\section{B. Share of the tourism economy in total GDP and employment}

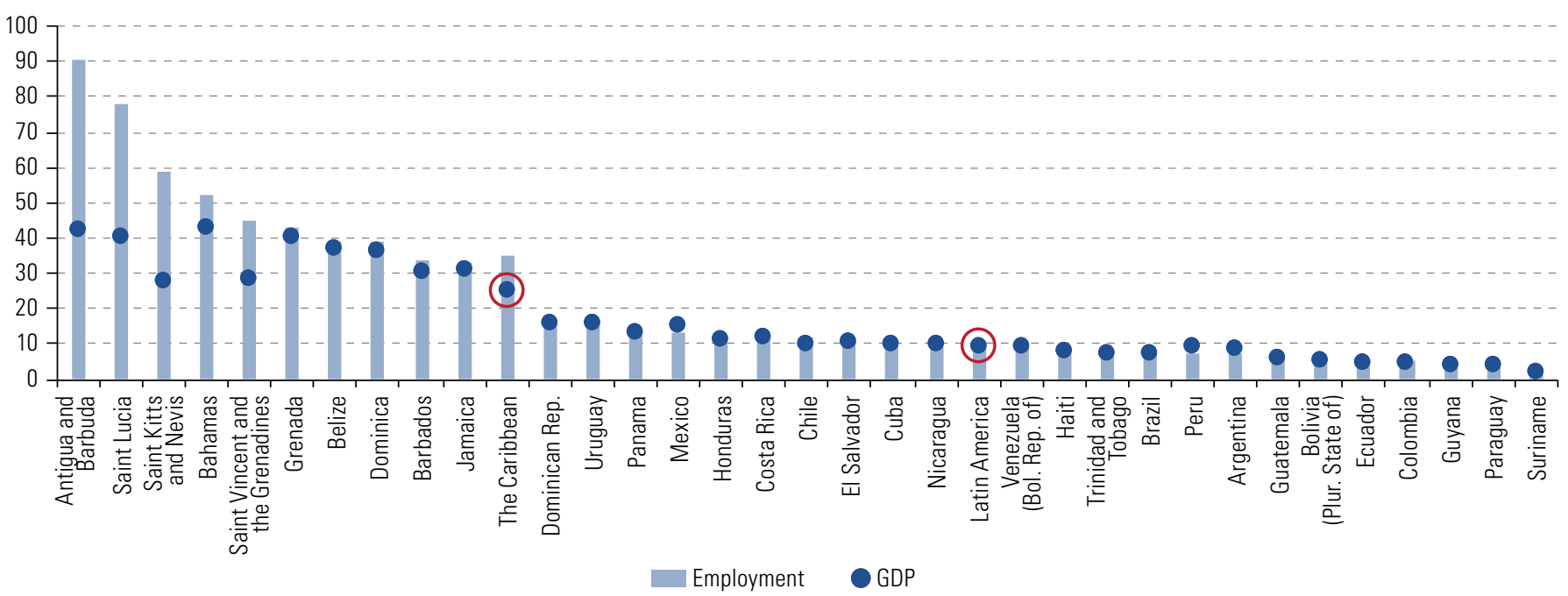

Source: Economic Commission for Latin America and the Caribbean (ECLAC), on the basis data from the World Travel and Tourism Council (WTTC) and World Bank, World Development Indicators [online] http://data.worldbank.org/data-catalog/world-development-indicators. Note: The tourism economy includes both tourism and all sectors that depend on it. The figures for Latin America and the Caribbean are unweighted country averages. The Caribbean includes all the member countries of the Caribbean Community (CARICOM) (except Montserrat), Cuba and the Dominican Republic.

Tourism offers key opportunities for women by providing flexible working hours and parttime jobs, although gender gaps remain. Women account for almost $60 \%$ of employment in the accommodation and food services sector in Latin America and 61\% in the Caribbean. Although many women work in low-level and low-paid jobs (UNWTO, 2019), half of all tourism businesses in the region are owned by women (World Bank, 2017).

Micro, small and medium-sized enterprises (MSMEs) represent the bulk of tourism firms For example, MSMEs accounted for $98.7 \%$ of tourism-related businesses in Costa Rica and 
99.8\%in Mexico (Tourism Satellite Account Costa Rica 2016 and Mexico 2018) (BCCR, 2018; INEGI, 2019). These ratios are similar to those of the whole Latin American economy, in which MSMEs account for $99 \%$ of the productive system and 61\% of employment (Dini and Stumpo, 2018).

\section{B. The dramatic fall in tourism}

The unfolding COVID-19 crisis has caused a major drop in tourism activity around the world, including Latin America and the Caribbean. Between 2016 and early 2020, tourist arrivals were growing at around $10 \%$ per year in Mexico and the three subregions. However, as the pandemic reached the region and an increasing number of countries closed their borders in March, tourist arrivals dropped by more than 50\% in March and close to 100\% in April in all three subregions and Mexico (see figure 2).

Figure 2

Latin America and the Caribbean (selected subregions):a annual variations in monthly international tourist arrivals, January 2016-April 2020

(Percentages)

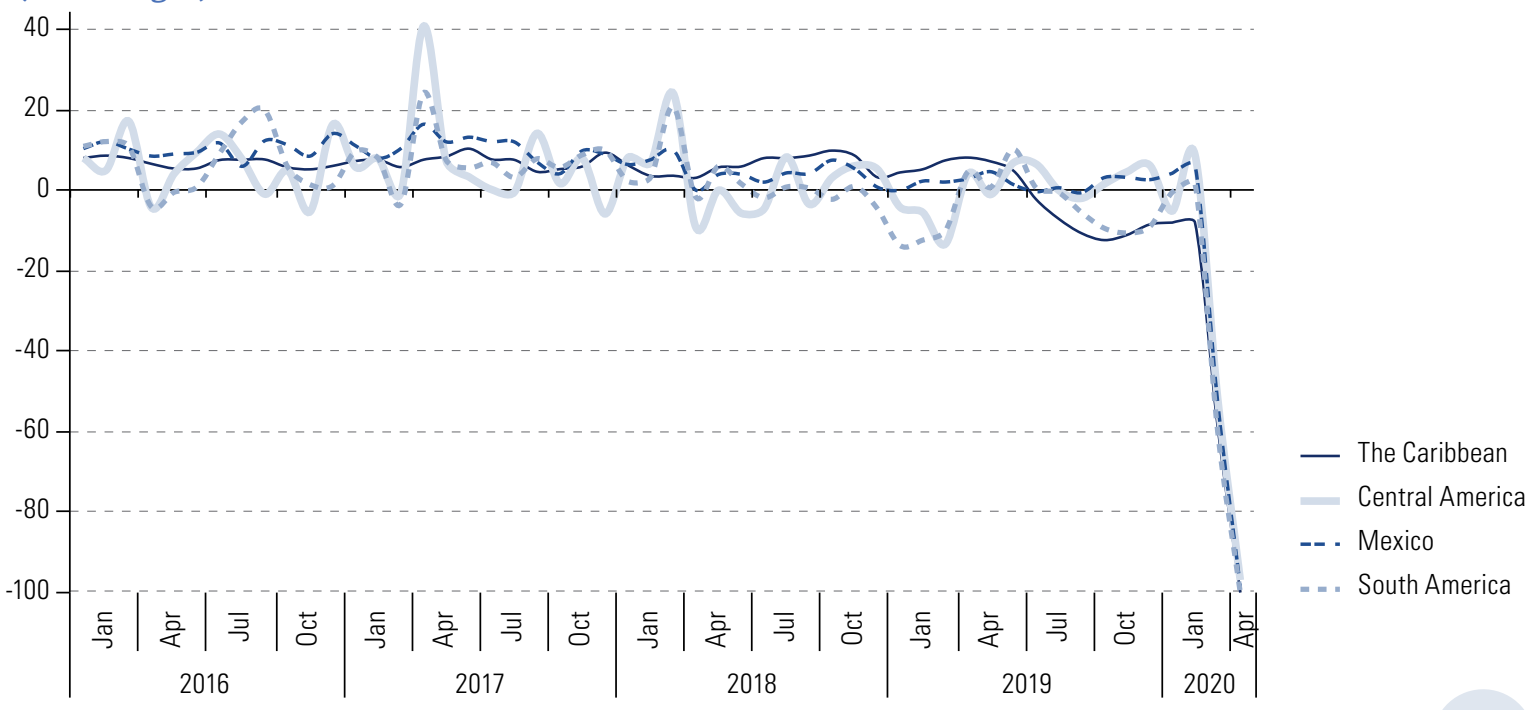

Source: Economic Commission for Latin America and the Caribbean (ECLAC) on the basis of official figures.

a The subregions include the following countries with complete monthly data: The Caribbean: Bahamas, Belize, Cuba, the Dominican Republic, Jamaica and Saint Lucia; Central America: Costa Rica and Guatemala; South America: Argentina, Chile, Ecuador, Peru and Uruguay.

International and domestic flights have also dropped to almost zero. Daily flight departures from airports in the different subregions fell abruptly during the second half of March (see figure 3), as did flight arrivals. Since April, most of the remaining flights have been for cargo or humanitarian purposes. Several of the major regional airlines (such as Avianca, Caribbean Airlines, Copa, LATAM and LIAT) have sought government support in the face of heavy income losses or bankruptcy (Antigua News Room, 2020a).

Within the tourism sector in the Caribbean, the cruise industry has been hit particularly hard. From 2010 to 2018, this sector was growing by 8\% per year on average. In 2019, the Caribbean welcomed 38\% of the global total of cruise ship passengers and $34 \%$ of total cruise ship deployment. However, as the pandemic spread around the world, passenger numbers had dropped to almost zero by mid-March 2020 (Panetta, 2020) 
Figure 3

Latin America and the Caribbean (selected subregions): daily flight departures, 1 March-12 June 2020

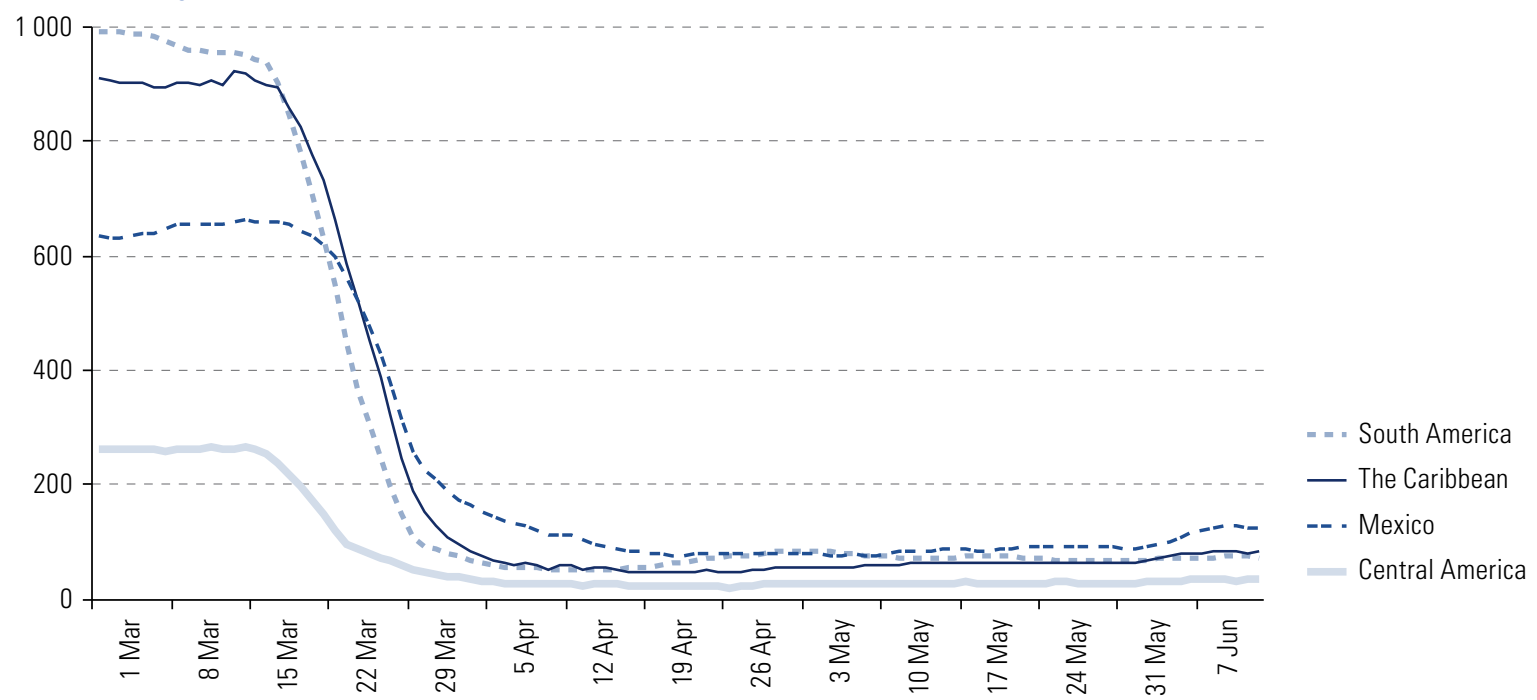

Source: Economic Commission for Latin America and the Caribbean (ECLAC) on the basis of International Civil Aviation Organization (ICAO) Global COVID-19 Airport Status, June 2020 [online] https://www.icao.int/safety/Pages/COVID-19Airport-Status.aspx

\section{Substantial impact on exports, GDP and employment}

The impact of the drop in tourism arrivals on exports, GDP and employment depends largely on the speed of the recovery in the second semester. Domestic travel will restart before international tourism, as restrictions on the former will be lifted sooner. Projections of future tourism activity must be based on monthly flows because of strong seasonal movements. Three scenarios are simulated owing to the high degree of uncertainty. As physical distancing will be the norm, tourism activity is expected to converge to plateaus of 50\%,60\% and $70 \%$ under the pessimistic, base and optimistic scenarios, respectively. For more details on the estimation method used, see box 1.

Box 1

Methodology to estimate the repercussions for exports, GDP and employment in Latin America and the Caribbean following the drop in tourism in 2020

The impact of the fall in tourism activity on total GDP, exports and employment is estimated as follows:

(a) Inbound tourism: (i) monthly international tourist arrivals are projected up to December 2021 using long-term trends; (ii) official data are used for arrivals between January and March 2020 (where available). International tourist arrivals are projected to drop 95\% in April 2020 and stagnate for several months at least according to the three scenarios. The subsequent recovery is expected to take around nine months, before reaching plateaus of $50 \%, 60 \%$ and $70 \%$ depending on pessimistic, base and optimistic scenarios, respectively (see table and figure below). The impact on total exports and GDP is estimated by multiplying the percentage difference in arrivals between the baseline forecast and recovery projection weighted by the share of inbound tourism in total exports and GDP, respectively. 
Box 1 (concluded)

Table

Three possible scenarios for the recovery of international tourism arrivals in 2020

\begin{tabular}{llc}
\hline Recovery scenario & Assumptions & $\begin{array}{c}\text { Projected fall in visitor } \\
\text { arrivals in 2020 }\end{array}$ \\
\hline Optimistic & $\begin{array}{l}\text { A 95\% drop in arrivals continues until June 2020. Countries manage } \\
\text { to control the pandemic and, from July, tourist arrivals gradually } \\
\text { recover to 70\% of the baseline forecast within } 9 \text { months. }\end{array}$ & $-52 \%$ \\
\hline Base & $\begin{array}{l}\text { The drop in arrivals continues until September 2020. The recovery } \\
\text { starts in October and arrivals return to 60\% of the baseline forecast } \\
\text { within } 9 \text { months. }\end{array}$ & $-67 \%$ \\
\hline Pessimistic & $\begin{array}{l}\text { The lockdown is relaxed in September 2020, but countries fail to } \\
\text { control the pandemic, experiencing a second wave of infections. } \\
\text { Travel restrictions are reinstated and last until December 2020. }\end{array}$ & $-72 \%$ \\
& $\begin{array}{l}\text { The recovery starts in January 2021 and arrivals return to 50\% of } \\
\text { the baseline forecast within } 9 \text { months. }\end{array}$ & \\
\hline
\end{tabular}

Source: Economic Commission for Latin America and the Caribbean (ECLAC).

Figure

Recovery of international tourist arrivals: three possible scenarios, 2020-2021

(Percentage of the baseline forecast)

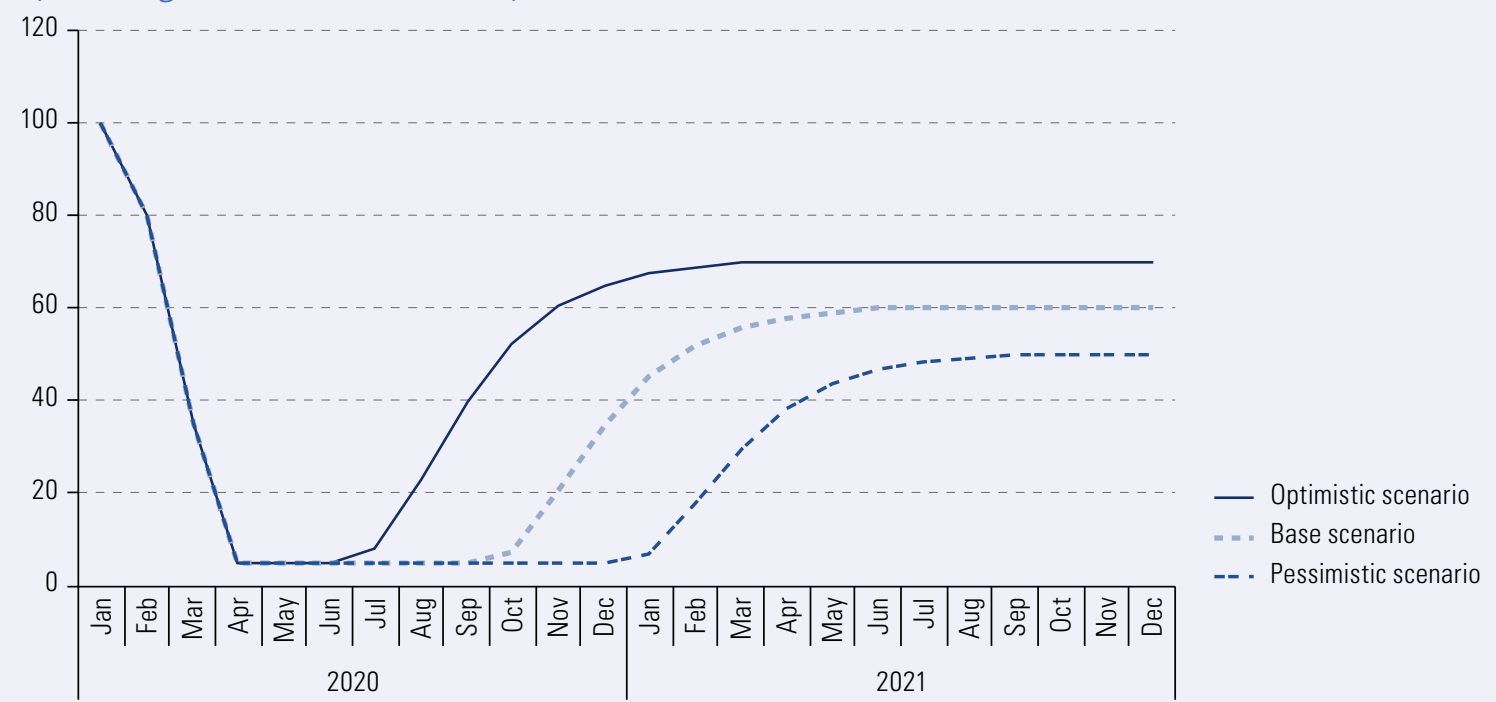

Source: Economic Commission for Latin America and the Caribbean (ECLAC).

(b) Domestic tourism: as January and February was the peak season for this segment in South America, it will be less affected than the rest of the region. It is assumed that domestic tourism activity (in terms of GDP) in the base scenario will fall 50\% relative to its 2019 level in South America and $60 \%$ in the rest of the region. The optimistic and pessimistic scenarios assume a drop of 20 percentage points below or above the base scenario, respectively.

(c) Potential employment loss is estimated using country-specific regressions of the relationship between employment trends and the growth cycle in tourism (Okun's law), see Kandil and others (2014). These provide employment-to-GDP elasticities, which, in turn, are applied to GDP losses. The employment estimates are upper bounds, as these do not take into consideration mitigation measures implemented by governments throughout the region.

Sources: Economic Commission for Latin America and the Caribbean (ECLAC), on the basis of Kandil and others (2014), "Labor market issues in the Caribbean: scope to mobilize employment growth", IMF Working Papers, No. WP/14/115, Washington, D.C., International Monetary Fund (IMF). 
Under these scenarios, six Caribbean economies may face losses of over $50 \%$ of their 2019 level of exports of goods and services, while another seven could face losses of over 20\%. For these Caribbean countries, the loss in tourism revenues will strongly curtail their capacity to import necessary goods and services (Coke-Hamilton, 2020). The relative export losses are expected to be smaller for Mexico and Brazil (see figure 4), in part because tourism in those countries depends much more on domestic tourists, rather than international arrivals. However, travel restrictions have also paralysed domestic travel, hitting these countries hard.

These steep falls in tourism revenues are likely to have a significant impact on overall GDP growth. In five Caribbean economies, the tourism crisis could reduce GDP by at least 10 percentage points, while in six others GDP could be cut by more than 6 points. Using slightly different assumptions, Mooney and Zegarra (2020) expect the crisis to have a similar impact on the GDP of these Caribbean economies. For all the South American economies analysed, the impact is expected to be below 2 percentage points, with Brazil seeing the smallest drop in GDP (see figure 5), owing to the relatively small weight of the sector in the overall economy.

The public health and economic crises are also expected to adversely affect employment in the tourism sector, particularly if the return of both domestic and international visitors is slow. According to the base scenario, which does not take into consideration the mitigation measures currently being implemented by all governments across the region to protect businesses and jobs, total employment may be reduced by 9 percentage points in the Caribbean and 2 percentage point in Latin America (see figure 6). In the Caribbean, Saint Lucia, the Bahamas, Antigua and Barbuda, Saint Kitts and Nevis and Grenada may suffer a total employment loss of 15 percentage points or more under the pessimistic scenario. Within Latin America, Mexico is expected to see the biggest drop in employment.

Figure 4

Latin America and the Caribbean (29 countries): impact of the downturn in tourism on exports of goods and services under three scenarios, 2020

(Percentages)

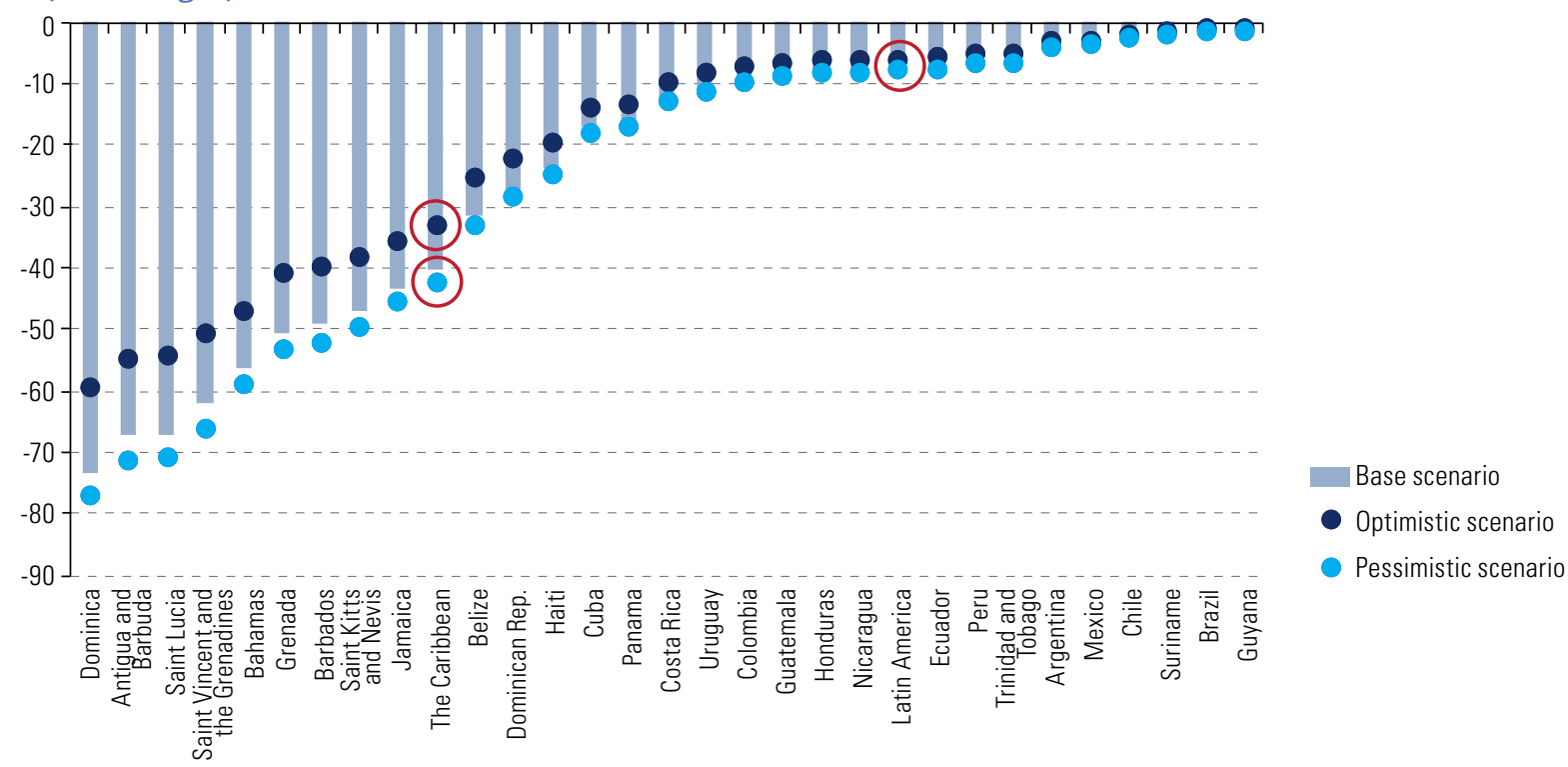

Source: Economic Commission for Latin America and the Caribbean (ECLAC). 
Figure 5

Latin America and the Caribbean (28 countries): impact of the downturn in tourism on total GDP under three scenarios, 2020

(Percentage points)

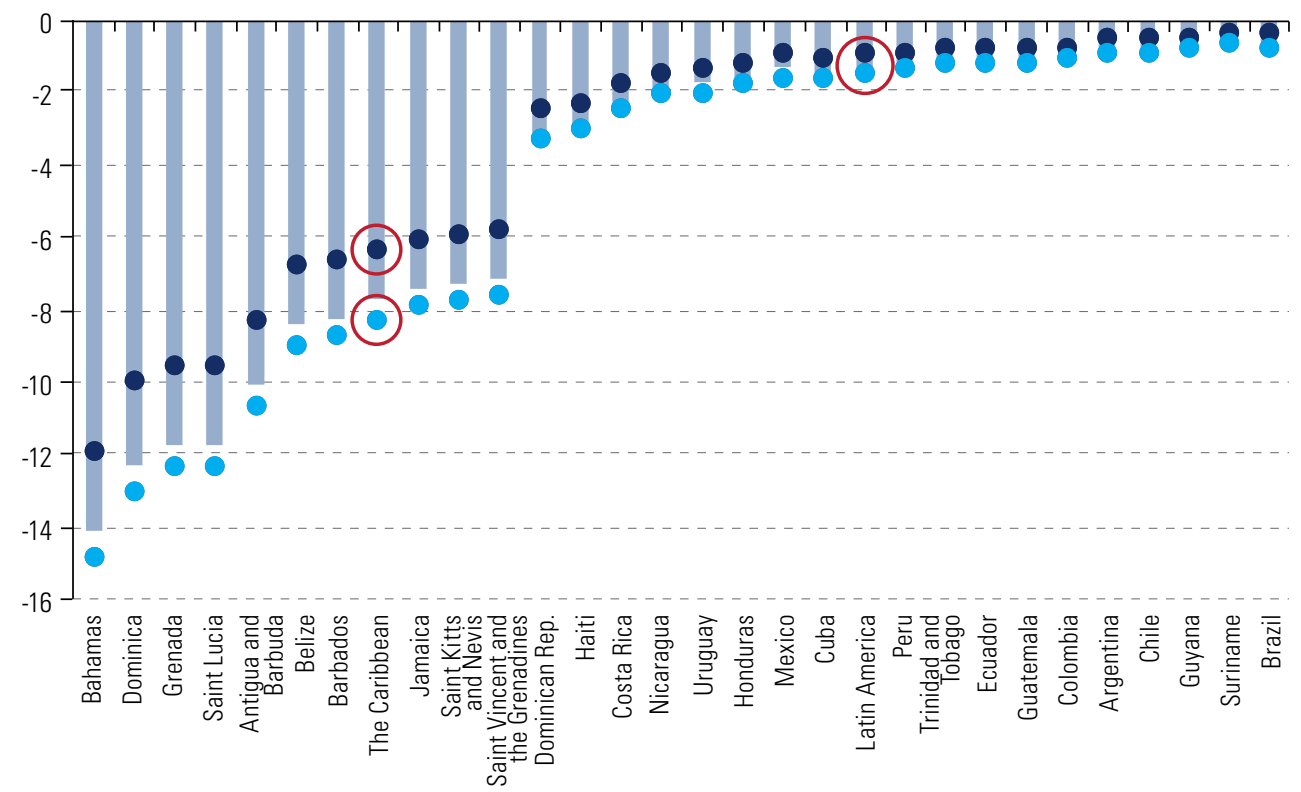

Base scenario

- Optimistic scenario

- Pessimistic scenario

Source: Economic Commission for Latin America and the Caribbean (ECLAC)

Figure 6

Latin America and the Caribbean (28 countries): impact of the downturn in tourism on total employment ${ }^{\mathrm{a}}$ under three scenarios, 2020

(Percentage points)

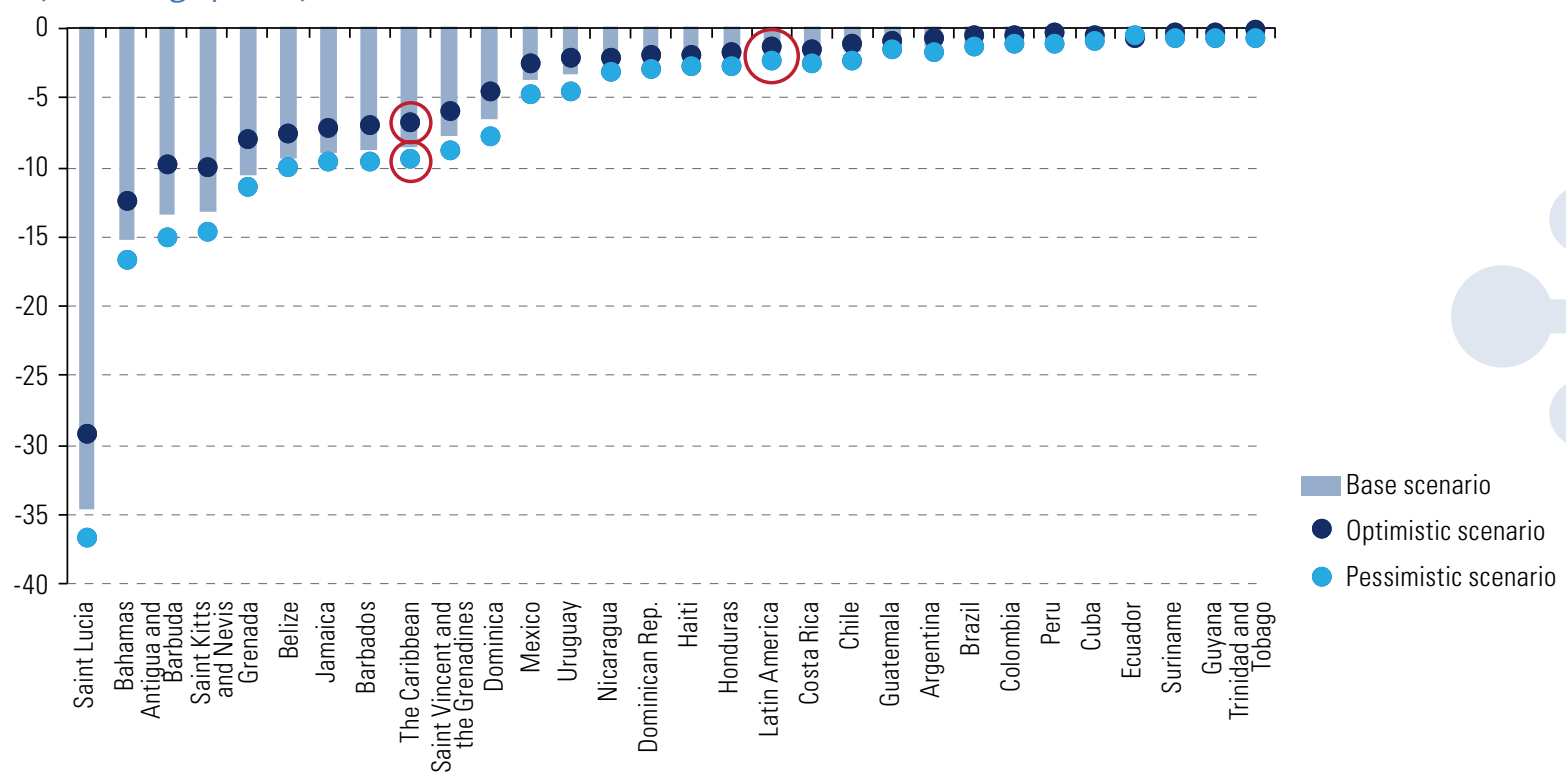

Source: Economic Commission for Latin America and the Caribbean (ECLAC)

a These are upper bound estimates that do not take into consideration the mitigation measures implemented to curb employment losses in the tourism sector. 


\section{Different measures can mitigate the impact of the crisis and accelerate recovery}

Countries in the region have taken measures to mitigate the economic and social impacts of the pandemic on tourism and prepare the sector for recovery. These recovery measures should also enhance the sector's diversification and its social and environmental sustainability.

\section{Job and income protections for workers}

Many countries have adopted fiscal packages to provide temporary income support to formal and, in some cases (Brazil), informal workers and business owners across the economy. In some countries, measures have been introduced to prevent firms from firing workers during a certain period (Argentina), or to allow employers and employees to reach agreements on reductions in working time and pay to avoid dismissals (Costa Rica). The Governments of the Bahamas, Belize and Jamaica have introduced temporary unemployment benefits for self-employed workers in all sectors and cash transfers for workers in the tourism sector, who are mostly women.

Employment in the tourism sector is characterized by high levels of informality and atypical work, such as part-time, temporary, casual, seasonal, self-employed and independent work. Workers carrying out essential tasks and front-line customer service employees have proven to be indispensable to the sector, but the crisis has also highlighted their vulnerability. Therefore, recovery plans must be based on the principle of decent work for all and include regulations covering labour and health rights.

\section{Support business survival, particularly that of MSMEs, throughout the tourism value chain}

Measures to support business survival include temporary exemptions or extensions for payment of corporate income tax (Saint Kitts and Nevis) (St Kitts \& Nevis Observer, 2020), value added tax (VAT) (Argentina and Colombia) and social security contributions (Chile, Colombia and Peru); reductions in the corporate income tax rate; credit lines (Ecuador) or subsidies (Guatemala) for working capital and (partial) wage payments for MSMEs and/ or large firms (the Bahamas, Brazil, Colombia and Costa Rica). The Government of Brazil is bearing $85 \%$ of the credit risk for loans to small and medium-sized enterprises, to be repaid over 36 months after a grace period of 6 months. In Ecuador and Panama, firms may postpone payments for electricity and water bills for 12 and 4 months, respectively.

In addition to immediate support, it is important to prepare MSMEs in the tourism sector for the future, specifically by building digital skills. Booking platforms and social media have allowed tourist providers to interact directly with their customers, eliminating intermediaries and reducing entry barriers. Digital skills also cover other innovative technologies, such as big data to track consumer behaviour and forecast demand, and artificial intelligence to design unique experiences.

\section{Facilitating the sector's short-term recovery}

Starting up tourism again after the pandemic will be challenging. Even though destinations may be objectively safe, many risk-averse travellers may seek to avoid exposure to COVID-19 and decide not to travel at all or to travel only short distances, avoiding air transport. Different measures can be taken to regain their trust. The most urgent is the adoption of preventive measures to minimize the spread of the disease. In several countries, the ministries of health and of tourism, technical standards institutions and the private sector are collaborating to define new protocols to minimize the risk of COVID-19 contagion. For example, a multi-stakeholder tourism recovery task force has been established in Antigua and Barbuda and Jamaica (Antigua News Room, 2020b; Jamaica Observer, 2020). Meanwhile, the Costa Rican Tourism Board (ICT) has published specific protocols for accommodation, transportation, national parks and other attractions (ICT, 2020). The private sector is developing its own health certifications, most notably Accor, the Spanish Association for Standardization and Certification (AENOR), Bureau Veritas (Iriarte Ahon, 2020) and the World Travel and Tourism Council (WTTC). 
The collapse of international arrivals has highlighted the need for diversification and has led several countries to promote domestic tourism to build resilience to shocks. Domestic tourism should have the dual function of reactivating the economy and recognizing the importance of access to leisure for everyone. In Mexico, domestic tourists account for $83 \%$ of the sector's revenues (INEGI, 2019). Therefore, the government is promoting travel experiences and brands in the country's 32 states (Secretariat of Tourism, 2020). An alternative approach to boost domestic tourism demand being explored in Chile, is to provide vouchers or discounts to lower income families or older persons.

Several countries have undertaken special marketing campaigns to attract new visitors in the near future. The Caribbean Tourism Organization (CTO) has posited that health and wellness could be a potential marketing point for the countries of the subregion (Barbados Today, 2020). The Secretariat of Tourism of Mexico published a promotional video to champion the country as a tourism destination. International marketing strategies should target those groups most likely to travel first, including luxury and business travellers, who can adopt physical distancing measures more easily and tend to favour less crowded locations.

Some of these strategies can be more easily implemented if tourism businesses operate within public-private clusters. Clusters are a geographic concentration of interconnected businesses, suppliers and other institutions with a strategic agenda for business upgrading and sophistication. Firms organized in clusters have strategic advantages to address the immediate challenges of the pandemic and define reactivation agendas. In Colombia, for example, there are 18 tourism clusters in different segments, including nature, business, health and cultural tourism.

\section{Promotion of the sector's medium-term sustainability and resilience}

This crisis is an opportunity to increase the contribution of tourism to the attainment of the 17 Sustainable Development Goals (SDGs) of the 2030 Agenda for Sustainable Development, while improving its resilience to disasters and climate change. Countries only have 10 years to meet the SDGs before the 2030 deadline. This year marks the beginning of the decade of action for the Sustainable Development, in which tourism is a key sector that contributes directly or indirectly to all the Goals, particularly SDG 8 (decent work and economic growth), SDG 13 (climate action); SDG 14 (life below water) and SDG 15 (life on land).

The pandemic mitigation measures currently being implemented for the tourism sector could be used to improve the sector's environmental and social sustainability, given that it accounts for approximately $5 \%$ of global greenhouse gas emissions, of which transportation is responsible for almost three quarters, followed by accommodation (one fifth). Tourism may cause substantial environmental damage under a business-as-usual scenario. However, taking the necessary measures to green this sector could reduce its impact considerably (OECD, 2018) and attract more environmentally conscious tourists.

\section{Regional cooperation}

Governments in the region should step up collaboration to keep cross-border transport networks as open as possible, paying particular attention to facilitating the transit and interchange of transport operators' crews (cruise, airline and logistics operators). Moreover, authorities should refrain from adopting measures that restrict in-transit traffic, except for measures necessary for safeguarding public health. To this end, digital solutions that limit physical contact at borders and protect the health of workers should be promoted.

Some initiatives have been introduced, mainly in the Caribbean Community (CARICOM), to foster cooperation and coordination to tackle the pandemic and its economic outfall. In early May 2020, the CARICOM Heads of Government agreed to establish a public-private subcommittee (including airlines, cruise operators, hoteliers and labour unions) to settle the appropriate protocols needed to ensure safety for workers and visitors upon reopening of the tourism sector (CARICOM Today, 2020a). In addition, the Trade and Economic Council of CARICOM also recommended Certificates of Operation be issued to tourism businesses that comply with these protocols (CARICOM Today, 2020b). Other subregional 
cooperation mechanisms, such as the Central American Tourism Integration Secretariat (SITCA), should be strengthened to tackle the pandemic.

The following actions could be coordinated at the subregional level:

- Create multi-country and multi-stakeholder crisis coordination teams to step up the exchange of information on travel-related health and other measures to limit the spread of the virus. These teams should include both tourism and regional public health organizations, such as the Pan American Health Organization (PAHO) and the Caribbean Public Health Agency (CARPHA).

- Develop joint guidelines and protocols to resuscitate travel and tourism, covering physical distancing and hygiene restrictions, the wearing of protective equipment, disinfection within ports and airports, and on board aircraft. International tourism organizations, such as UNWTO and WTTC, are guiding these efforts.

- Strengthen bilateral or subregional agreements to facilitate transit for travellers from signatory countries.

- Promote cooperation among national tourism organizations and relevant stakeholders in the areas of health, transport and immigration, to better coordinate measures to mitigate the impact of COVID-19.

- Foster the exchange of good practices among countries to tackle the crisis, including connectivity, coordination, national relief efforts and measures to support the tourism sector

- Create and implement a post-COVID-19 crisis recovery plan, which should seek to enhance national and regional tourism capabilities; engage industry stakeholders to increase business and consumer confidence; explore innovative solutions using digital technologies to stimulate the tourism sector; coordinate marketing efforts; improve the resilience of tourism; and promote sustainable and inclusive tourism.

- Assess the social, economic and environmental impacts of cruise ship tourism, and define regional standards moving forward.

- Promote South-South cooperation to develop Tourism Satellite Accounts and standardize tourism data.

\section{Bibliography}

Antigua News Room (2020a), "LIAT further extends suspension of passenger services", 14 May [online] https://antiguanewsroom.com/liat-further-extends-suspensionpassengers-services/.

(2020b), "Tourism industry stakeholders meet virtually to discuss plans for Antigua \& Barbuda tourism re-opening", 9 May [online] https://antiguanewsroom.com/ tourism-industry-stakeholders-meet-virtually-to-discuss-plans-for-antigua-barbudatourism-re-opening/.

Barbados Today (2020), "CTO: Brace for '25-year' tourism setback", 1 May [online] https:// barbadostoday.bb/2020/05/01/cto-brace-for-25-year-tourism-setback/.

BCCR (Central Bank of Costa Rica) (2018), "Cuenta Satélite de Turismo" [online] https:// www.bccr.fi.cr/seccion-indicadores-economicos/cuenta-sat\%C3\%A9lite-de-turismo.

CARICOM Today (2020b), "STATEMENT - Tenth Special Emergency Meeting of the Conference of Heads of Government of the Caribbean Community (CARICOM), Via Video Conference, 5 May 2020", 11 May [online] https://today.caricom.org/2020/05/07/statementtenth-special-emergency-meeting-of-the-conference-of-heads-of-government-ofthe-caribbean-community-caricom-via-video-conference-5-may-2020/.

(2020b), "CARICOM's Trade and Economic Council approves strategy for the re-opening of regional economies", 12 May [online] https://today.caricom.org/2020/05/07/ caricoms-trade-and-economic-council-approves-strategy-for-the-re-opening-ofregional-economies/ 
Coke-Hamilton, P. (2020), "Impact of COVID-19 on tourism in small island developing States", United Nations Conference on Trade and Development (UNCTAD), 24 April [online] https://unctad.org/en/ pages/newsdetails.aspx?OriginalVersionID=2341.

Dini, M. and G. Stumpo (coords.) (2018), "Mipymes en América Latina: un frágil desempeño y nuevos desafíos para las políticas de fomento", Project Documents (LC/TS.2018/75), Santiago, Economic Commission for Latin America and the Caribbean (ECLAC)

ICT (Costa Rican Tourism Board) (2020), "Material de apoyo coronavirus (sector turismo)" [online] https:// www.ict.go.cr/es/servicios-institucionales/material-de-apoyo-coronavirus-sector-turismo.html.

INEGI (National Institute of Statistics and Geography) (2019), “Cuenta Satélite del Turismo de México" [online] https://www.datatur.sectur.gob.mx/SitePages/ProductoDestacado3.aspx.

Iriarte Ahon, E. (coord.) (2020), "Informe: lineamientos y herramientas que, bajo un enfoque innovador y con énfasis en la transformación digital, buscan promover el sector turismo en el corto, mediano y largo plazo tras el Estado de Emergencia Nacional por el COVID-19, considerando los nuevos cambios de paradigmas del viajero nacional e internacional, que exigirá que los prestadores de servicios turísticos se reinventen para sobrevivir", May, unpublished

Jamaica Observer (2020), "Tourism minister confirms opposition seat on COVID-19 Tourism Recovery Taskforce", 24 April [online] http://www.jamaicaobserver.com/latestnews/Tourism_minister_confirms_ opposition_seat_on_COVID-19.

Mooney, H. and M. A. Zegarra (2020), "COVID-19: tourism-based shock scenarios for Caribbean countries", Inter-American Development Bank (IDB), 16 March [online] https://blogs.iadb.org/caribbean-dev-trends/ en/covid-19-tourism-based-shock-scenarios-for-caribbean-countries/.

OECD (Organization for Economic Cooperation and Development) (2018), "Analysing megatrends to better shape the future of tourism", OECD Tourism Papers, No. 2018/02, Paris, OECD Publishing.

Panetta, G. (2020), "Cruise ship bookings for 2021 are already on the rise despite multiple COVID-19 outbreaks", Business Insider, 12 April [online] https://www.businessinsider.com/cruise-ship-bookingsare-increasing-for-2021-despite-coronavirus-2020-4

Secretariat of Tourism (2020), 'Presenta Miguel Torruco la estrategia digital para la contención de crisis del sector turístico", 8 April [online] https://www.gob.mx/sectur/prensa/presenta-miguel-torruco-laestrategia-digital-para-la-contencion-de-crisis-del-sector-turistico

St Kitts \& Nevis Observer (2020), "COVID-19: Government's 17-Point Stimulus Package Includes Reducing Corporate and Business Tax", 25 March [online] https://www.thestkittsnevisobserver.com/covid-19governments-17-point-stimulus-package-includes-reducing-corporate-and-business-tax/

UNWTO (World Tourism Organization) (2019), Global Report on Women in Tourism - Second Edition, Madrid (2020), World Tourism Barometer, vol. 18, No. 2, May.

World Bank (2017), Women and Tourism: Designing for Inclusion, Washington, D.C.

This document is part of a series of reports prepared by the Economic Commission for Latin America and the Caribbean (ECLAC) on the evolution and effects of the COVID-19 pandemic in Latin America and the Caribbean. It was prepared by the International Trade and Integration Division, directed by Mario Cimoli, in collaboration with the ECLAC subregional headquarters for the Caribbean, the ECLAC subregional headquarters in Mexico and the ECLAC office in Brasilia, under the general coordination of Alicia Bárcena, Executive Secretary of ECLAC.

Copyright (C) United Nations, 2020

Economic Commission for Latin America and the Caribbean (ECLAC)

Comisión Económica para América Latina y el Caribe (CEPAL)

www.eclac.org 